$\mathrm{npj} \mid$ Microgravity

ERRATUM OPEN

\title{
Erratum: A cubesat centrifuge for long duration milligravity
} research

Erik Asphaug ${ }^{1}$, Jekan Thangevelautham ${ }^{1}$, Andrew Klesh ${ }^{1,2}$, Aman Chandra ${ }^{1}$, Ravi Nallapu ${ }^{1}$, Laksh Raura ${ }^{1}$, Mercedes Herreras-Martinez ${ }^{1}$ and Stephen Schwartz ${ }^{1}$

npj Microgravity (2017)3:24; doi:10.1038/s41526-017-0025-9

Erratum to: npj Microgravity (2017); doi:10.1038/s41526-017-0021-0; Published 05 June 2017

In the HTML version, Figs. 5 and 6 were duplications of other figures. These figures have now been removed in the HTML version of this Article.

Open Access This article is licensed under a Creative Commons Attribution 4.0 International License, which permits use, sharing, adaptation, distribution and reproduction in any medium or format, as long as you give appropriate credit to the original author(s) and the source, provide a link to the Creative Commons license, and indicate if changes were made. The images or other third party material in this article are included in the article's Creative Commons license, unless indicated otherwise in a credit line to the material. If material is not included in the article's Creative Commons license and your intended use is not permitted by statutory regulation or exceeds the permitted use, you will need to obtain permission directly from the copyright holder. To view a copy of this license, visit http://creativecommons. org/licenses/by/4.0/.

(c) The Author(s) 2017

\footnotetext{
${ }^{1}$ Arizona State University, Tempe, AZ, USA and ${ }^{2}$ Jet Propulsion Laboratory, Pasadena, CA, USA
}

Correspondence: Erik Asphaug (easphaug@asu.edu)

Published online: 05 September 2017 